\title{
The Piano: A Psychoanalytic Approach to Movie as A Media of Reflective Teaching
}

\author{
Erna Wardani \\ Universitas Jenderal Soedirman \\ erna.wardani@unsoed.ac.id
}

Article History:

First Received:

$09 / 06 / 2020$

Final Revision:

$29 / 06 / 2020$

Available online:

$30 / 06 / 2020$
Abstract. Freud's psychoanalytic approach has been one of the most controversial approaches to many fields of interest. Relating to education and educational psychology, this approach plays a significant role in modifying and enhancing one's behavioral relationship among the educational elements like educators, parents, and students. Therefore, in many things, this approach has contributed a lot of inspiration in the development of education. In literary works, there seems to be a mutual fascination between psychoanalysis and literature whereas theory and approach, psychoanalysis explains literature and literature itself exploits psychoanalysis for creative purposes and works. Here, as a creative work, movie is considered literature because it can be interpreted and analyzed just like other written works of literature. As a learning instrument, movie evokes an affective domain that leads to changes in learning behavior and attitudes. Experiencing certainthemed movies can trigger particular reflective memories and reference toward events occurring on a daily basis and it can further strengthen the foundation for learning complex concepts like psychoanalysis.

Keywords: The Piano, psychoanalysis, psychoanalytic approach, reflective teaching

\section{http://jos.unsoed.ac.id/index.php/jes}

\section{INTRODUCTION}

There is nothing new about the psychological approach, in the general sense of the word. In Transfer and Katharsis, Freud to Aristotle, as early as 4 BC, Aristotle used it as a fusion of the emotions of sympathy and fear to generate catharsis in his classic interpretation of tragedy (Turri, 2015). Sir Phillip Sidney psychologized literary works during the English Renaissance with his declarations on the positive impact in morality of poetry, as were romantic poets such as Coleridge, Wordsworth and Shelley with their theory of imagination (Lamb, 1994). Then, during $20^{\text {th }}$ century, a particular school of thought came out to mark its significant appearance: the psychoanalytic theories of Sigmund Freud [1856 - 1939]. 
According to Kenny (2016) in her article A Brief History of Psychoanalysis: From Freud to Fantasy to Folly, the basis for the distinctive viewpoint of Sigmund Freud is his focus on the unconscious dimensions of the human psyche. Freud presented compelling evidence through his many carefully documented case studies that the majority of our acts are guided by psychological forces over which we have very little control. He showed that the human mind is built like the iceberg, such that its great weight and mass lie beneath the surface; it is below the level of consciousness. Freud further emphasizes three major premises in his approach as the following (Kamil \& Abidin, 2013):

1. The main assumption of the psychoanalysis approach is that all behavior can be explained in terms of the inner conflicts of the mind.

2. Freud highlights the role of the unconscious mind, the structure of personality and the influence that childhood experiences have on later life.

3. Freud believed that the unconscious mind determines most of our behavior and that we are motivated by unconscious emotional drives.

Starting from these three premises, Freud defines the mental processes to three psychic zones or the tripartite model: the id, the ego, and the superego (Kenny, 2014).

- Id: It is the biological part (instincts and drives) of the personality. It is present at birth. It is irrational, instinctual, unknown, unconscious, containing secret desires, wishes, and fears. It demands instant gratification of its needs. It is also lawless, asocial, and amoral. Id houses the libido, source of psychosexual desires, untamed passion, aggressions, and psychic energy; pleasure or primordial life principle resides in id.

- Ego: It develops from 1 - 3 years. It is motivated by the reality principle. It mediates the conflicts between the ID and superego. It uses defence mechanisms to achieve this rational, logical, waking part, corresponds to the reality principle; it regulates desires from id.

- Superego: It develops from 3 - 5 years. It is motivated by the morality principle. It punishes the ego with guilt for "wrong doing". It is the censor of inappropriate desires according to social norms, working through punishment in form of guilt and fear. It serves also as the moral censoring agency, the repository of conscience and pride.

Figure 1. Sigmund Freud Psychoanalytic Theory

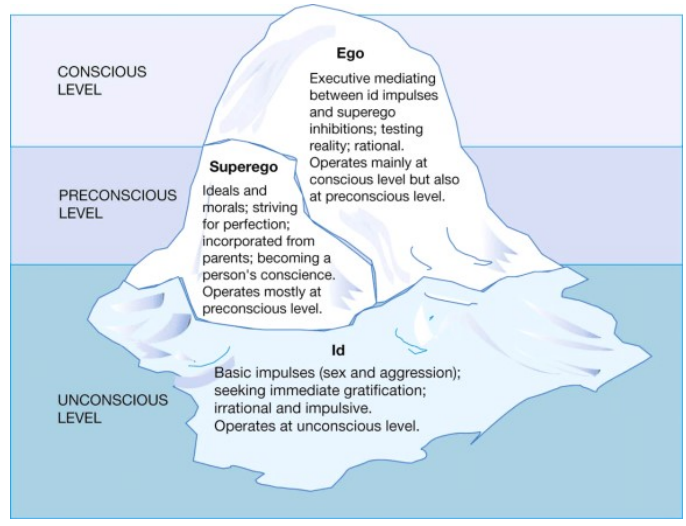

To be psychologically balanced the brain must be able to balance the ego's and the superego 's demands. If the superego is dominant, a person can develop a neurosis, e.g. depression. Further, the person will develop a disorder, e.g. schizophrenia, if the Id is dominant. 
The influence of Freud on many fields of interest like modern literature, critical practice, and even education has been so immense and varied that no small selection from his work can begin to represent that influence. For Freud, literature stuff is the unresolved conflicts which give rise to any neurosis. A literary work, he claims, is the outward manifestation of the unconscious mind of the author and the literary work must therefore be interpreted as a vision (Hossain, 2017). Here, movies are highlighted as a modern literary work that can be an interesting connection between its creator to its audience like students to communicate basic concepts and theories on certain grounds as well as personal values and perspectives. Further, in Education through Movies: Improving Teaching Skills and Fostering Reflection among Students and Teachers, Blasco et al (2015) mentions that in educational world, movies are employed as an effective media to boost visual development in its relation to text and hearing.

In addition, movies are accessible, allowing the students to acquire the knowledge without difficulty, involving the emotional memory centers, so that the information is better and faster remembered. In this paper, The Piano, a movie by Jane Campion, is used as a media in reflective teaching to observe the way the students behave in the classroom and to evaluate how the lecture share the discussion points during the lesson. The movie shares valuable lessons on how someone, especially a woman, should be in charge of one's life, have certain options, and be a subject of desire rather than an object.

\section{RESEARCH METHOD}

This work uses a descriptive method, depending on the process of short movie clips. Here, the researcher teaches the class with clips that bring together multiple rapid scenes, which is a favourable way of watching a whole movie. Because of their brevity, pace, and emotional strength it makes sense to use movie clips in this context (Levey, 2015). Levey further notes that while the abruptly shifting scenes in the clips effectively invoke the individual thoughts of the learners and promote reflection, commenting as the clip plays serves as a powerful catalyst to the entire cycle. Because learners are involved in their personal reflective process, they may come up with divergent comments that are particularly useful for facilitating the process of reflection (Blasco et al, 2015). The approach involves an open conversation after the movie clips are shown, in which the students ask questions and express their opinions, emotions and ideas. This approach will help other teachers strengthen their self-knowledge, and through the affective domain, establish closer relationships among students (Blasco et al, 2006).

\section{RESULT AND DISCUSSION}

\section{The Piano: A Brief Psychoanalysis Perspective}

Ada McGrath 's struggle to choose between passion and health, between life and death in a harsh New Zealand setting is central to The Piano. The movie director, Jane Campion, adds to this genre many modern elements, creating a complex fictional character that evokes powerful psychological reactions in the other characters and in the audience. A psychoanalytic viewpoint sheds some light on this 
film's complexity and influence as it uses silence, evolving sexuality, anxiety of the primal scene, and romantic redemption to attract the public (Hanigsberg, 1995).

The Piano is a film that succeeds in its study of sexuality construction, and the damaging effect of discourses of institutionalized domination on personal relations. It stresses the need for cultural recognition of an individual autonomy, thereby destroying the morality of the patriarchy of the nineteenth century which dictated sexual repression and ownership (Greenberg, 1994). Love as an integral element of sexual relationships is presented as a major theme in the film, combined with the concept of love which conveys mutual respect as well as desire. At the other hand, Hanigsberg (1995) also states that sexual activity is shown to be not only irrationally unfair but also catastrophic as a condition of patriarchal transactions such as arranged marriage.

In Review: Jane Campion's Piano, Jan Chapman, Harvey Greenberg (1994) states that The Piano shows us abandoned, isolated, constricted characters who suffer in silence but do almost anything to feel alive and preserve that vitality. The characters of Jane Campion are as emotionally limited as the crated piano on the remote New Zealand beach, as lonely as Ada (starred Holly Hunter) who can play the piano but who can't talk or won't.

The Piano overflows with emotion as it uses Freudian erotics and archetypal images to explore the prison and liberation of a woman. The film starts in shadows with what seems to be thick, indistinct bars (Hanigsberg, 1995). This depicts Ada in this first picture signifying her own state of isolation. The bars are her hand holding up before her eyes. Campion, the director practically shows her protagonist Ada's perspective from the imprisoned eyes of her own character. Ada's voice-over establishes the plot's underlying premise: as a young girl she vowed never to speak, and persevered with an iron will. What we hear is not her speaking voice but the self-imprisoned voice that sounds within her mind, she tells us. At times, Ada's iron will is mysterious and somehow it doubles the quality of Ada's psyche - - free will and imprisonment will -- we have the guiding binary opposition of The Piano (Gillett, 2004).

The movie's Victorian setting brings it similar in time and style to the sexual exploitation that produced Freudian theories of the unconscious and eventually of all persuasions psychoanalysis. The oppressive restrictions on gender, sexuality, and emotions compelled life to express itself in signs of torture. Ada's piano, trapped in her muteness, is the sole source of her liberation -- conducting works of her own making. Playing the piano is her consuming and sacred passion, a cry of the free spirit up to heaven and her music is art as the release of imprisoned passion.

In the film's opening sequence, the audience is instantly confronted with an entirely contractual picture of marriage: "Today he [Ada 's father] married me to a man I haven't yet met." Strong-willed and non-conforming, Ada embraces the agreement but is not completely positive about it. She already has a daughter, too, but the question of the validity of the child remains unanswered. Such considerations indicate possible tension with her future husband's patriarchal authority over the identity of his partner, and introduce the plot's primary power discourse: the commodity status of the female protagonist through the patriarchal system's negation of female autonomy. 
The character of Alisdair Stewart (starred Sam Neill) reflects European patriarchal values; he symbolizes repression, the narrowing of gender into an unemotional atmosphere of female passivity and male dominance. The film reveals the mentalities of wealth, which have contributed to the destruction of the nature environment, but also to the degradation of personal connections. He illustrates this by at the beginning of the film rejecting Ada's own claim, the piano, to George Baines' land (starred Harvey Keitel). Stewart refuses to acknowledge her right to it and to understand that she is furious because of this. His sense of property often applies to her sexuality; when his sense of power over her is challenged, he attempts to rape her twice to assert his dominance, to force her into submission. Stewart is incapable of appreciating sexuality when he is not in the dominant position. His patriarchal understanding of sexuality is so narrow that he is unable to understand Ada's need to develop a degree of intimacy with which she is relaxed.

Phillip Gillett (2008) in Movie Greats: A Critical Study of Classic Cinema explains that this movie aims to offer an alternate view of sexuality, one in which power discourse is not an agreed requirement as it is within the parallel sexuality of the European colonialists. In the juxtapositions of the two groups, clothing often plays a fascinating role. The Maoris are comfortable with their almost-nude and environmentally-friendly garments. This contrasts with the colonialists' dress; both sexes wear several layers of restrictive clothing, yet, it is the European females whose dress is particularly confining, with a tight corset and broad, uncomfortable hoop skirt, symbolizing the cultural constraints of femininity.

Meanwhile, Baines' definition of sexuality is much less historically constructed than Stewart's, as he himself has less of a colonialist patriarchal background. He has the Maori facial tattoo and speaks the language. Baines has regard for equality, both culturally and sexually; the Maori women in his household are not submissive as they are in the other colonial residences. Baines respects female sexuality and he also agrees that women are equal to men on this matter. Therefore, he doesn't use violence against Ada because he doesn't want to impose his will over hers. He acknowledges the value the piano has for Ada which Stewart fails to do.

Clearly, Baines has little interest in the piano. Nevertheless, he talks to Ada, if she tolerates his indecent sexual advances as she play the tunes, she will have her piano back, key by key. Despite her anger and frustration, Ada's desire for piano is significant. She is trapped, and Baines continues using her in a one-sided relationship involving rape and forced prostitution. Yet, Ada's willingness gets stronger as Baines upsets the stakes, more keys in return for more of Ada's sexual favors. Baines has liberated something in Ada by granting her the ability to bargain with him: her independence (Gillett, 1995).

Later on, Ada betrays Stewart when she sends a piano key to Baines with the words engraved: "Dear George, You have my heart, Ada McGrath." Flora betrays her mother's wish and gives Stewart the piano key. Stewart, in a wild rage, drags Ada out of the house through rain and mud into the chopping block where he chops off her right-hand index finger with an axe. When he tells Flora to give the wrapped finger to Baines, he warns agonizingly, " ... if he ever tries to see her again I'll take off another and another and another!" The violent threat from Stewart is a hellish transformation of the Ada-Baines deal (Gordon, 1996). 
The characters overcome their internal conflicts only through their sacrifices and conquer their loneliness in an unexpected manner. To understand the theme of sacrifice, we need to return to the theme of the symbolic relationship between the piano keys and Ada's fingers (Gillett, 1995); the piano keys that hold Ada's affection and Ada's fingers that touch the keys erotically and then touch Baines and Stewart's naked bodies. Baines is aroused to see the polished ivory pounded by Ada 's fingers. Within the deal between Ada and Baines the piano keys are bartered and traded piece by piece: Baines offers to return the piano within exchange for one visit per key. His egalitarian masculinity, affection, and open curiosity awaken Ada's sexuality first, then her love later on. He is the one who understands the sexual desire with which Ada plays the piano. He bursts into Ada's sublimated autoeroticism (Gordon, 1996) with his own barbaric showing and then both are trapped by their shared passion.

Here, Baines questions the conventional power sexuality debate within marriage. The idea of sexual possession is shown to be false, though the patriarchy of the nineteenth century treated women themselves as a tradable commodity. Ada refuses her husband's intimate affairs; her sexual identity always belongs to her and she opts to enter the intimate relationship with Baines. The Piano does not depict her adultery as an act of immorality; it is sex without love which Baines specifically criticizes in the movie (Gillett, 1995). Baines' feminism clearly rejects male dominance. He talks to Ada as an equal adult, while Stewart treats her as an infant.

Ada and Baines both need love to have a sexual relationship, and love equates freedom from discourses of control. It is in sharp contrasts with Stewart's definition of romantic relationships. Stewart seems to be totally unaware that he must receive affection through trust, loyalty and love; none of which he gives to Ada. Baines and Ada are both experiencing a turning point in their feelings for one another. To Baines, it is when he gives her back the piano, that he is unable to continue their relationship (Gillett, 2004). He says, "I want you to take care of me." For Ada, she understands her commitment to him after this act of kindness, and their sexual relationship has become emotional too. Here it discusses a reversal of traditional emotional constructs. Male emotional weakness due to sexual intimacy is entitled, rather than female (Klinger, 2006), and as Baines inquires, "... does this mean anything to you, Ada? Do you love me?"

Throughout the film, the piano as an entity assumes the meaning and sexuality of Ada's body. The instrument is sold, and the possession of misplaced property interest is protected for both Stewart's piano trading and her father's arranged marriage to Ada; the piano is no more Stewart's to trade than Ada is by the males who hold authority over her. As the piano is her most effective means of speech, Stewart's decision to trade is almost like his act of cutting off her finger: acts of violence, the castration of her independence (Gillett, 1995). The ways Stewart and Baines show in identifying the piano echo their idea of female sexuality. Baines is aware of the importance of the piano to Ada and his first act of kindness is to get it tuned. It reflects Baines' admiration for it, and his concern for women's sexuality in general. To him the piano achieves explicit sexual significance when it comes to reflecting the body of Ada. Previously, he is depicted polishing it in the nude and to him, it is a cherished and solemn rite about the behavior suggesting that he is serious about his attraction to Ada. Here, for Baines, sexuality is not about control but about 
love and adoration (Gillett, 2008). Conversely, Stewart's attempted rape scene in the forest is mirrored with the scenes of the Maori men thumping and pounding on the piano, conveying a message of physical disrespect and aggression (Greenberg, 1994). Just when Flora comes to find her in distress and cries, "They're touching your piano!" Ada is rescued.

The Piano comes to an end to symbolize Ada's sexuality; as the center of her tragedy, her misery is the focus of this movie. Her new life with Baines in Nelson is described as a sexuality rebirth and the piano throwing to the ocean and Ada's near death express the burial of sexual repression and the loveless dialogue of dominance between her and Stewart. While learning to speak, Ada wears a black veil possibly symbolizing the fact that Ada is not sexually 'pure' according to conventional patriarchal values (Hanigsberg, 1995). The purity of their union is the quality of sexual respect and equality which connects them in their love for each other. The scene conveys the concept that the endorsement of sexuality by Ada and Baines is based on love and acceptance over lust but also unrepressed emotion. They have found a place through which they can openly express their sexuality, but it remains their own, for there is no victory over another from one discourse.

\section{The Piano: A Reflection in The Classroom}

The movie clips from The Piano are taken from YouTube channel. The titles and the links are in the following:

Table 1. The Piano Movie Clips

\begin{tabular}{|l|l|c|l|}
\hline No & \multicolumn{1}{|c|}{ Clip Titles } & Duration & \multicolumn{1}{|c|}{ Links } \\
\hline 1 & The Piano - The Promise & $3: 15$ & $\begin{array}{l}\text { https://www.youtube.com/watch?v= } \\
\text { hEf6CD7azCE }\end{array}$ \\
\hline 2 & The Piano - The Bride & $3: 10$ & $\begin{array}{l}\text { https://www.youtube.com/watch?v= } \\
\text { biidFs35qQM }\end{array}$ \\
\hline 3 & $\begin{array}{l}\text { The Piano }- \text { He chopped it } \\
\text { off! }\end{array}$ & $8: 20$ & $\begin{array}{l}\text { https://www.youtube.com/watch?v= } \\
\text { yLJQwpIrt2c }\end{array}$ \\
\hline 4 & A Weird Lullaby & $6: 18$ & $\begin{array}{l}\text { https://www.youtube.com/watch?v= } \\
\text { fTn4ibTb_sw }\end{array}$ \\
\hline
\end{tabular}

The movie clips are played in Psikologi Pendidikan (Educational Psychology) class for two meetings. These clips assist the teaching and learning processes when the topic is about theories of educational psychology. At that time, there was a discussion about the function of psychoanalysis approach in education. After the open discussion, the class members come to some points about the lessons from the movies and how psychoanalysis perspective can support the classroom activities.

In the first meeting, the class discusses about Freud's concept of anxiety. Anxiety belongs to the domain of Ego (Waqas, 2015) that warns any students, of possible up-and-coming 'dangerous' and uncomfortable learning conditions. In this case, the teacher makes students prepared and able to show appropriate adaptive reactions toward those conditions. In education, students' anxiety concept can be 
managed and organized by the teachers or counselors for the betterment of the students themselves and their learning development. In other words, their anxiety is shifted to a kind of training to their affective domain development or character development. The procedures of the first reflective teaching are as follows:

$1^{\text {st }}$ Reflective Teaching

1. Before playing the first movie clips, the students are given a brief introduction of Freud's tripartite model: the id, the ego, and the superego.

2. The teacher groups the students into a group of 3-4 students.

3. $1^{\text {st }}$ movie clip: The Piano - The Promise

4. The teacher asks questions: Which person is anxious? How do you know?

5. The teacher randomly chooses the students to answer the questions.

6. $2^{\text {nd }}$ movie clip: The Piano - The Bride

7. The teacher asks questions: Do you find another new anxious person? How does the person do to overcome anxiety?

8. The teacher randomly chooses the students to answer the questions.

9. The students are asked to recall and write down their vivid experience of being anxious in their school time.

10. The students are asked to recall their past reaction and solution to the condition.

11. The teacher asks the students to give their possible present reaction and solution to the same condition.

12. The teacher asks whether there is/are similar and/or different reaction and solution.

13. The teacher asks whether there is/are similar and/or different points from the movie clips compared to the students' present condition in general.

14. The students write down their brief reflections and comments.

15. The teacher chooses 3 groups to have open discussion about how to cope with anxiety, how to deal with anxious students, and how to minimize anxiety in teaching and learning processes.

The second meeting, the discussion focuses on students' aggression. Here, a teacher must serve also as an educator to control and manage students' affective domain leading to positive condition. In Education and Aggression, Stan \& Tudorică (2015) mention that aggression is students' psychological behavior to gratify their destructive impulse to upset or to intimidate others. It can also be said that this aggressive action is an expression of unacceptable dissatisfaction. Negative judgment and harmful utterances are said to be some triggering factor of such an action. Therefore, if students perform mistakes, severe words and brutal reaction can directly lead to lasting psychological distress and worsen their learning process. The treatments for aggressive students may vary from personal counseling session to responsibility entrust in doing small-scale community service project. The procedures of the second reflective teaching are as follows:

\section{$2^{\text {nd }}$ Reflective Teaching}

1. Before playing the first movie clips, the students are given a brief introduction of Freud's mental levels: conscious, preconscious, and unconscious.

2. The teacher groups the students into a group of 3-4 students. 
3. $1^{\text {st }}$ movie clip: The Piano - He chopped it off!

4. The teacher asks questions: Which person is aggressive? How do you know?

5. The teacher randomly chooses the students to answer the questions.

6. $2^{\text {nd }}$ movie clip: A Weird Lullaby

7. The teacher asks questions: What do you think of being aggressive? Is aggression always related to being uncontrollable and expressive?

8. The teacher randomly chooses the students to answer the questions.

9. The students are asked to recall and write down their vivid experience of being aggressive or finding someone aggressive in their school time.

10. The students are asked to recall their past reaction and solution to the condition.

11. The teacher asks the students to give their possible present reaction and solution to the same condition.

12. The teacher asks whether there is/are similar and/or different reaction and solution.

13. The teacher asks whether there is/are similar and/or different points from the movie clips compared to the students' present condition in general.

14. The students write down their brief reflections and comments.

15. The teacher chooses 3 groups to have open discussion about how to cope with aggression, how to deal with aggressive students, and how to minimize aggression in teaching and learning processes.

The following are some reflections and comments resulted and noted from the open discussions with the students.

Table 2. Reflections and Comments on The Piano

\begin{tabular}{|c|c|c|}
\hline No & Clip Titles & Reflections and Comments \\
\hline 1 & The Piano - The Promise & $\begin{array}{l}\text { 1. Paling suka liat scene pas Ada ngeliat piano } \\
\text { dari kejauhan. Separuh jiwanya pergi.. } \\
\text { 2. Silence is the most powerful weapon for } \\
\text { everybody when the person really wants } \\
\text { something but he or she cannot get it. } \\
\text { 3. Harusnya bisa nahan si ID kalo mau bawa } \\
\text { piano. Ini kan pantai..ada pasir, anginnya asin, } \\
\text { jaman segitu emang ada yang mau nyetem } \\
\text { piano. Eh..ini kan film ya Mam..tapi kan bisa } \\
\text { juga di alam nyata.. } \\
\text { 4. Aku kok liatnya lebih 'beradab' Baines yaa..pas } \\
\text { dia bilang, "She looks tired." Tampang Bang } \\
\text { Napi, hati Hello Kitty deh.. } \\
\text { 5. Sesuatu yang ditekan pasti akan meledak. } \\
\text { Harus bisa cari jalan keluarnya..solusinya..tapi } \\
\text { yang jangan merugikan orang lain. }\end{array}$ \\
\hline 2 & The Piano - The Bride & $\begin{array}{l}\text { 1. Kecemasan bisa terjadi pada semua } \\
\text { orang...segala usia. Anak-anak, remaja, dewasa. } \\
\text { Tinggal cari pihak yang mau mendengarkan } \\
\text { dan kasih solusi yang pas. }\end{array}$ \\
\hline
\end{tabular}




\begin{tabular}{|c|c|c|}
\hline & & $\begin{array}{l}\text { 2. Aneh tapi nyata..biasanya kalo bapak" cemas } \\
\text { kan menyendiri. Ini malah ngegosip sama } \\
\text { emak"..tapi enak juga kali ya Mam ada yang } \\
\text { mau ngedengerin kita berkeluh kesah. Dikasih } \\
\text { teh anget pulak.. waahh gak nolak deh Mam.. } \\
\text { 3. Am I anxious? Yes! What do I do? I try to find a } \\
\text { good listener. Am I a good listener? Well, I'm } \\
\text { trying to be the one. }\end{array}$ \\
\hline 3 & $\begin{array}{l}\text { The Piano - He chopped it } \\
\text { off! }\end{array}$ & $\begin{array}{l}\text { 1. Think twice kalo perlu 1000x harus bolak balik } \\
\text { mikirnya..biar ngga nyesel.. } \\
\text { 2. Nyesek banget Ma'am! Kayak gini jadinya ya } \\
\text { kalo terburu nafsu. } \\
\text { 3. Itu efek ke anaknya gimana yaa..bahaya } \\
\text { banget memang trauma masa kecil }\end{array}$ \\
\hline 4 & A Weird Lullaby & $\begin{array}{l}\text { 1. Masa lalu ya masa lalu..buang barang mantan } \\
\text { ke laut..tenggelamkan! Case closed! Hidup Bu } \\
\text { Susi! (Maap ya Mam..bercanda wkwkwk) } \\
\text { 2. I think everybody should move on and make } \\
\text { peace with him/herself. } \\
\text { 3. Forgiven but not forgotten }\end{array}$ \\
\hline
\end{tabular}

The value in teaching with movie clips is further analyzed and reinforced through the students' feedback and field note-taking during the open discussion sessions. The teacher can clearly spot emotions in the faces of students as they watch the movie clips and hear the remarks of their peer. The students often show emotions that are easier to appraise, while other kinds of emotions, such as anger or disgust, run between lines.

It is discovered that the methodology is not simply to feel emotions, but to help connect the issues raised in the movie clips to the students' daily lives recently such as thinking many times before posting publicly personal message on social media when anger erupts or pondering the theoretical feedbacks when the thesis proposal is rejected. Relating to this case, as an effective crossroads between emotions and behavior, self-reflection can encourage change in attitude processes (Lubis, 2018). Naturally, there is still a long way to go even when a specific message reaches the students. Changing behavior is quite challenging. The emotional commitment will extend to the logical brain to form the basis for substantive change.

The students agree that this form of teaching helps them focus on themselves individually, allowing them to think about who they are, what they want in their lives and what they have to do. The importance of the critical messages of the movie clips can be easily linked to students' everyday life. Here, Freud's approach to psychoanalysis has a strong way of analyzing human actions and the detrimental effects of needless restrictions. One note from the students also says that Freud's focus on the role of gender in one's life may illustrate the need to provide children with proper sex education.

In addition, the researchers' aim is not only to release emotions, but also to evaluate how students move away from their emotions and immerse themselves in 
personal reflection, and how they can apply lessons learned from the movie clips into their daily lives in real and concrete ways. Such interactions are real educational mechanisms and open door to behavioral modulating attitudes.

\section{CONCLUSION}

Freud's psychoanalysis idea helped to understand the origin of ailing behavior. This idea can be required to provide proper extracurricular activities and appropriate hobbies in school curricula if applied further in the educational environment. This part has to do with developments in the behavior of learners and other psychological fields such as cognitive, psychomotor and affective. For educators, being aware of the learners' own emotions and recognize other learning approaches may turn such feelings into valuable instructional and educational resources, in order to overcome these inter-related psychological changes.

\section{REFERENCES}

An Apology for Poetry and Poems, 1579, Philip Sidney. (2020). Retrieved from https://shakespearebrasileiro.org/en/an-apology-for-poetry-and-poems1579-philip-sidney/

Anna Freud (1954) Psychoanalysis and Education, The Psychoanalytic Study of the Child, 9:1, 9-15, DOI: 10.1080/00797308.1954.11822532

Anwar, K. (2014). Problematika Belajar dalam Perspektif Psikologi Pendidikan. Jurnal Pelopor Pendidikan, 6(2), 105-107.

Britzman, Deborah. P. (2013). What gives with psychoanalysis and education? Journal of the American Association for the Advancement of Curriculum Studies, Volume 9

Britzman, Deborah. P. (2015). A psychoanalyst in the classroom: On the human condition in education. Albany, NY: State University of New York Press.

Bertens, K. (2016). Psikoanalisis Sigmund Freud. Jakarta: Gramedia

Blasco, Pablo Gonzalez et al. (2006). Using Movie Clips to Foster Learners' Reflection: Improving Education in The Affective Domain. Fam Med. 38(2):946.

Blasco, Pablo Gonzalez et al. (2015). Education through Movies: Improving teaching skills and fostering reflection among students and teachers. Journal for Learning through the Arts, 11(1). Retrieved from https://escholarship.org/uc/class_lta/11/1

Brookfield, S. (1995). Becoming A Critically Reflective Teacher. San Francisco, CA: Jossey Bass.

Frankenstein, Carl. (1966). The Roots of the Ego: A Phenomenology of Dynamics and of Structure. Baltimore: The Williams \& Wilkins Co. 
Gillett, Phillip. (2008). Movie Greats: A Critical Study of Classic Cinema. New York: Berg

Gillett, Sue. (1995). Lips and Fingers: Jane Campion's The Piano. Screen, 36(3), 277287. https://doi.org/10.1093/screen/36.3.277

Gillett, Sue \& Australian Teachers of Media. (2004). Views from Beyond The Mirror: The Films of Jane Campion. St Kilda, Victoria: ATOM

Gordon, Suzy. (1996). 'I clipped your wing, that's all': Auto-erotism and The Female Spectator in The Piano Debate. Screen, 37(2), 193-205. https://doi.org/10.1093/screen/37.2.193

Greenberg, Harvey. (1994). Review: The Piano by Jane Campion, Jan Chapman. Film Quarterly. 47(3):46-50. https://doi.org/10.2307/1212959

Hanigsberg, Julia E. (1995). An Essay on The Piano, Law, and the Search for Women's Desire. Michigan Journal of Gender and Law, 3(1), Retrieved from https://repository.law.umich.edu/mjgl/vol3/iss1/3

Hatton, Neville \& David Smith. (1994). Facilitating Reflection: Issues and Research. (Paper presented at the Conference of the Australian Teacher Education Association (24th, Brisbane, Queensland, Australia, July 3-6, 1994)).

Retrieved from https://eric.ed.gov/?id=ED375110

Hossain, Md. Mahroof. (2017). Psychoanalytic Theory used in English Literature: A Descriptive Study. Global Journal of Human-Social Science: G Linguistics \& Education. Volume XVII. Issue I. Version I. Retrieved June 24, 2020, from https://globaljournals.org/GJHSS_Volume17/3-Psychoanalytic-Theoryused.pdf

Implications for Education Using Frueds Theory. (2017, Jan 04). Retrieved from https://studymoose.com/implications-for-education-using-frueds-theoryessay

Kamil, Muhammad Jameel Mohamed \& Abidin, Shahriman Zainal. (2013). Unconscious Human Behavior at Visceral Level of Emotional Design. Procedia - Social and Behavioral Sciences. 105. 149-161. 10.1016/j.sbspro.2013.11.016. Retrieved June 24, 2020, from https://www.researchgate.net/figure/Freudsiceberg-model-of-unconscious-pre-conscious-and-consciouslevels_fig1_259524711

Kenny, Dianna Theadora. (2014). From Id to Intersubjectivity: Talking about The Talking Cure with Master Clinicians. London: Karnac.

Kenny, Dianna Theadora. (2016). A brief history of psychoanalysis: From Freud to fantasy to folly. Psychotherapy and Counselling Journal of Australia. http://pacja.org.au/?p=2952. 4th Edition. 1-26. Retrieved June 24, 2020, 
The Piano: A Psychoanalytic Approach to Movie as A Media of Reflective Teaching

- Erna Wardani (p.68-81) 80

from

https://www.researchgate.net/publication/307561841_A_brief_history_of_p sychoanalysis_From_Freud_to_fantasy_to_folly

Klinger, Barbara. (2006). The Art Film, Affect and The Female Viewer: The Piano Revisited. Screen, 47(1), 19-41. https://doi.org/10.1093/screen/hjl002

Korthagen, Fred A. J. \& Theo Wubbels. (1991). Characteristics of Reflective Practitioners: Towards and Operationalization of the Concept of Reflection. (Paper presented at the Annual Meeting of the American Educational Research Association (Chicago,IL, April 3-7, 1991)). Retrieved from https://eric.ed.gov/?id=ED334183

Kuswandono, Paulus. (2012). Reflective Practices for Teacher Education. LLT Journal: A Journal on Language and Language Teaching, 15(1). DOI: https://doi.org/10.24071/llt.2012.150102

Lamb, M. (1994). Apologizing for Pleasure in Sidney's "Apology for Poetry": The Nurse of Abuse Meets the Tudor Grammar School. Criticism, 36(4), 499-519. Retrieved June 24, 2020, from www.jstor.org/stable/23116102

Levey, Brian R. (2015). Using Film Clips in the Classroom: Something Old, Something New? Journal of Teaching and Learning with Technology, Vol. 4, No. 2, December 2015, pp.41-50. doi: http://dx.doi.org/10.14434/jotlt.v4n2.13140

Lubis, Arief Husein. (2018). Reflective teaching toward EFL teachers' professional autonomy: Revisiting its development in Indonesia. International Journal of Education, 11(1), 35-49. doi: http://dx.doi.org/10.17509/ije.v11i1.9400

Ramzy, I. (1956). From Aristotle to Freud; a few notes on the roots of psychoanalysis. Bulletin of the Menninger Clinic, 20(3), 112-123. Retrieved from https://pubmed.ncbi.nlm.nih.gov/13316324/

Richards, Jack. (1991). Towards Reflective Teaching. The Teacher Trainer. 5. Retrieved from https://www.researchgate.net/publication/265934213_Towards_Reflective_ Teaching

Richards, Jack C. \& Theodore S. Rodgers. (2001). Approaches and Methods in Language Teaching. ( $2^{\text {nd }}$ Ed.). Cambridge: Cambridge University Press

Stan, Emil \& Bogdan Tudorică. (2015). Education and Aggression. Procedia - Social and Behavioral Sciences, Volume 203, 374-379, https://doi.org/10.1016/j.sbspro.2015.08.3111 
Syah, M. (2010). Psikologi Pendidikan dengan Pendekatan Baru. Bandung: Rosdakarya

Taubman, Peter. (2012). Disavowed Knowledge: Psychoanalysis, Education, and Teaching. NY: Routledge Press.

The Freud Encyclopedia: Theory, Therapy, and Culture. 2001. Edward Erwin(Ed.). London: Routledge

Turri, Maria Grazia. Transference and katharsis, Freud to Aristotle. The International Journal of Psycho-analysis. Vol. 96,2 (2015): 369-87. doi:10.1111/17458315.12243. Retrieved from https://pubmed.ncbi.nlm.nih.gov/25327434/

Waqas, Ahmed et al. (2015). Association of Ego Defense Mechanisms with Academic Performance, Anxiety and Depression in Medical Students: A Mixed Methods Study. Cureus, 7(9): e337. DOI 10.7759/cureus.337. Retrieved from https://www.researchgate.net/publication/282325178_Association_of_Ego_ Defense_Mechanisms_with_Academic_Performance_Anxiety_and_Depression_ in_Medical_Students_A_Mixed_Methods_Study

Yalof, Jed. (2015). Teaching Psychoanalytic Concepts in the University

Setting: Issues, Challenges, and Promises. Psychoanalytic Inquiry: A Topical Journal for Mental Health Professionals. 35:sup1. 124-134. DOI: 10.1080/07351690.2015.987598 